\title{
Renal Metastasis of Esophageal Squamous Cell Carcinoma- A Case Report and Literature Review
}

\author{
Yu-Sheng Lin ${ }^{1}$, Kun-Yuan Chiu ${ }^{1 *}$, Siu-Wan Hung ${ }^{2}$ and Hsin-Ni $\mathrm{Li}^{3}$ \\ ${ }^{1}$ Division of Urology, Department of Surgery, Taichung Veterans General Hospital, Taichung, Taiwan \\ ${ }^{2}$ Department of Radiology, Taichung Veterans General Hospital, Taichung, Taiwan \\ ${ }^{3}$ Department of Pathology, Taichung Veterans General Hospital, Taichung, Taiwan
}

"Corresponding Authors: Dr. Kun-Yuan Chiu, Division of Urology, Department of Surgery, Taichung Veterans General Hospital, Taichung, Taiwan, Tel: +886-4-23741215; Fax: 886-4-23595046; E-mail: chiu37782002@yahoo.com

Received: 04 January 2018; Accepted: 23 January 2018; Published: 31 January 2018

\begin{abstract}
Esophageal cancer rarely metastasizes to the kidney. The metastatic organs known more commonly are the liver, lung, and bone. Here, we report a case of a 58 year-old male, who had been diagnosed with squamous cell carcinoma of the esophagus 22 months ago, developed renal metastasis. He subsequently received nephrectomy and adjuvant chemotherapy. We also reviewed similar cases in the literature. This case report could alert physicians caring patients of esophageal carcinoma to pay more attention to the less common renal metastasis.
\end{abstract}

Keywords: Kidney; Metastasis; Esophageal Cancer; Squamous cell carcinoma

\section{Introduction}

Esophageal cancer is the $8^{\text {th }}$ commonest cancer worldwide, with an estimated 456,000 new cases in 2012 (3.2\% of the total), and the $6^{\text {th }}$ commonest cause of death from cancer with an estimated 400,000 died in the same year (4.9\% of the total) [1]. In Taiwan, esophageal cancer is in 2015 the $9^{\text {th }}$ leading cause of death [2]. During the period from 2001 to 2007, the overall 5-year survival rate for esophageal cancer is 19\% [3]. Once distant metastasis occurs, the overall 5-year survival rate drops below 5\%. The common sites of metastasis are in descending order, the liver, lung, 
bone and adrenal gland. Metastasis to kidney is extremely rare for esophageal carcinoma, with only a handful of cases reported so far [4-19]. We present here a case of esophageal squamous cell carcinoma that has metastasized to one kidney and we also reviewed the relevant literature.

\section{Case Report}

A 58-year-old male had been in his normal health before December, 2014, a time when he experienced difficulty in swallowing, poor appetite and body weight loss (10 kg in two months). A month later, the symptoms progressed and he developed nausea, vomiting after eating.Consequently, he came to our hospital for help. Panendoscopic findings revealed an esophageal mass. The biopsy result supported the diagnosis of squamous cell carcinoma. Then on January $30^{\text {th }}, 2015$, he started the first course of neoadjuvant concurrent chemoradiotherapy (chemotherapy with Cisplatin, 5-FU and radiotherapy with 3600cGy, or CCRT). By March, 2015, after finishing two courses of CCRT, partial remission was achieved. On April $20^{\text {th }}$, 2015, he underwent robotic-assisted thoracoscopic esophagectomy. The histopathological finding was squamous cell carcinoma, moderately differentiated. Tumor had invaded to the adventitia including one lymph node. The pathological staging was $\mathrm{pT}_{3} \mathrm{~N}_{1} \mathrm{M}_{0}$. After surgery, he did not continue chemotherapy due to poor general conditions and his reluctance to receive more treatment. In November, 2016, he again visited the Urology clinic because of gross hematuria occurring over the past three weeks, and he had accompanied flank pain on the right side. An abdominal computed tomography (CT) showed an infiltrative lesion over the right upper pole kidney with suprarenal involvement (Figure 1). Ureteroscopic biopsy of the upper calyx of right kidney was performed and results were negative for malignancy. CT guided biopsy was then performed and histopathology showed an invasive carcinoma with squamous differentiation. He received a regimen of three times adjuvant chemotherapy under the suspicion of metastatic esophageal squamous cell carcinoma. Follow-up CT scans showed right renal tumor that was further enlarged in size. Right radical nephrectomy and lymphadenectomy were performed in March, 2017. Histopathological findings confirmed squamous cell carcinoma of invading the right kidney and ureter, moderately to poorly differentiated (Figure 2). The margin was uninvolved by invasive carcinoma and the pathological staging was $\mathrm{pT}_{4} \mathrm{~N}_{0}$. The urothelium was intact without tumor invasion. Therefore, we judged that the renal tumor was metastatic. After the surgery, he received systemic treatment with Bortezomib (Velcade) weekly and Leucovorin (HDFL) biweekly for to control distant metastasis.

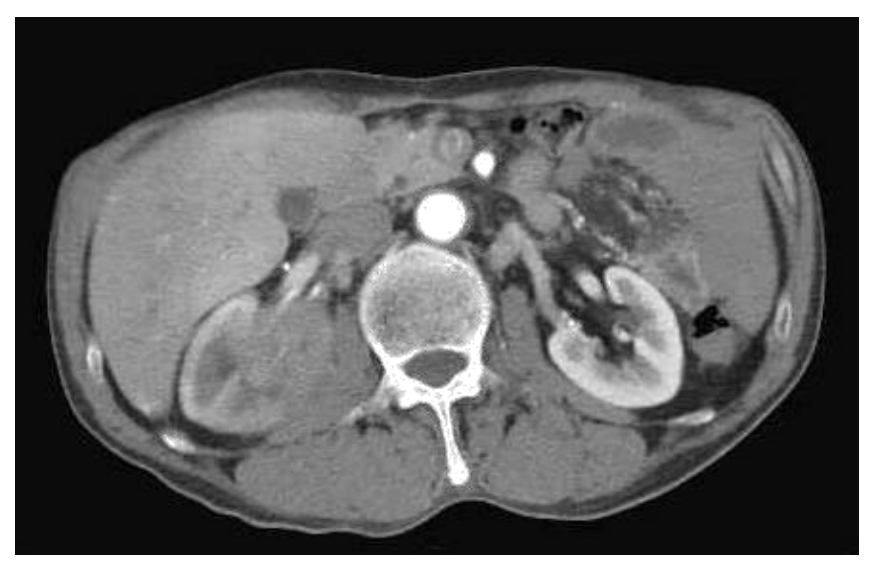

Figure 1: An Axial computed tomography (CT) image of the patient showing a poor enhancing infiltrating lesion over the right upper pole of his kidney(arterial phase). 


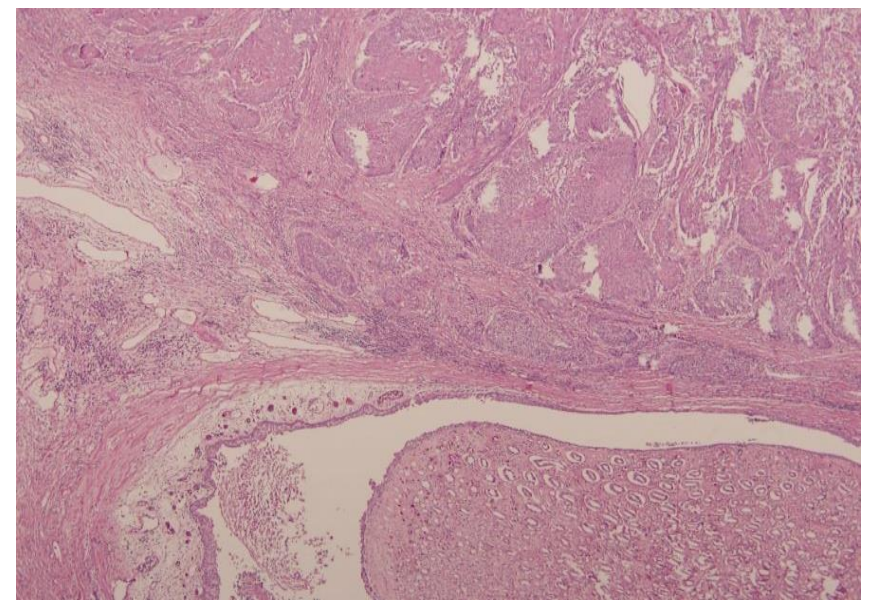

Figure 2: Histopathologic micro-photograph of the renal tumor. Note keratinizing squamous nets infiltrating the renal parenchyma. The urothelium is intact without malignancy. (Hematoxylin \& Eosin stain, 40x).

\section{Discussion}

Esophageal cancer is notoriously aggressive in nature, spreading by a variety of pathways including direct extension, lymphatic spread and hematogenous metastasis. Its prognosis largely depends on the extent of local invasion as well as the spread to regional and distant structures [20]. We reviewed reported cases of esophageal cancer with metastasis to kidney and summarized them in Table 1 . We found a total of 18 cases in the literature, with the first one reported in 1987 by Pollack et al. Among the 18 patients, the overwhelming majority of them $(n=17)$ have squamous cell carcinoma, and only one case is adenocarcinoma. Also, all patients except one are male. Most of the patients $(n=16)$ are from populations in Asia(including Chinese, Japanese and Korean ethnicity), while only two patients are of French. The overall survival time duration after renal metastasis ranges from two months to over 9 years. According to one geodemographic study on esophageal cancer, the squamous cell carcinoma is found more prevalent in Asia than in Western countries, where the adenocarcinoma is on the contrary more common [20]. Additionally, adenocarcinoma in general has a prognosis better than squamous cell carcinoma. Siewert et al. reported a level $40 \%$ on the 10-year overall survival of patients with Barrett's-associated cancer, whereas that of squamous cell carcinoma is $20 \%$ [21]. It is worth noting that the only case of adenocarcinoma is of Chinese ethnicity and this patient has also the longest survival after renal metastasis. From the reviewed cases, one is tempted to speculate that squamous cell carcinoma of the esophagus has a greater tendency than the adenocarcinoma to metastasize to the kidney. This speculation is consistent with the present case which is also a squamous cell carcinoma. The common sites of distant recurrence of esophagus cancer are, in the descending order of frequency: lymph node (45\%), liver (35\%), lung (20\%), cervical/supraclavicular lymph node (18\%), bone (10\%), adrenal gland $(5 \%)$, peritoneum (2\%), and brain (1.5\%) [22]. Kidney metastasis is rarely detected clinically and is most often only detected at autopsy. Anderson et al presented the autopsy of 79 patients with esophageal carcinoma, and found that the common metastatic sites are lymph node (73\%), lung (52\%), and liver (47\%), with kidney accounting for only $13 \%$ [23]. The discordance of clinical and autopsy findings may be due to the fact that the occurrence of renal metastasis is often asymptomatic. In one study on kidney metastasis patients, only $33 \%$ of then have showed the symptom of microscopic hematuria, and $15 \%$ gross hematuria [24]. Some patients may have proteinuria. Renal 
failure is rare unless accompanied by obstructive uropathy [4]. The diagnosis of renal metastasis is therefore often found unecpected on regular examinations. In our literature review of renal metastasis, 7 of the 18 reported cases are asymptomatic; 10 are presented with hematuria or flank pain and only complains of general weakness and body weight loss. Therefore, for early dection, it is necessary to screen closely renal metastasis in patients with esophageal cancer [18]. There is currently no consensus regarding the treatment of esophageal cancer with renal metastasis due to the scarcity of cases. Related to this issue, we reviewed the $2017 \mathrm{NCCN}$ guidelines of esophageal cancer [25]. For metastatic squamous cell carcinoma of esophageal cancer, systemic treatment is recommended if the patient has a good performance status (Karnofsky performance score $>60 \%$ or ECOG performance below 2). For adenocarcinoma of esophageal cancer, the HER2 test should be done and Trastuzumab should be added to chemotherapy for HER2 overexpressing metastatic adenocarcinoma. However, based on imaging study alone, it is difficult to differentiate whether the tumor is primary transitional cell carcinoma of renal pelvis or metastatic carcinoma. Both metastatic carcinoma of kidney and primary advanced stage of transitional cell carcinoma could appear as infiltrating tumor with renal parenchyma invasion [26, 27]. Therefore, nephrectomy is often done in such cases. Of the 18 cases reviewed, all patients except one have received nephrectomy. Once the metastatic carcinoma has been confirmed, chemotherapy should be started.

\begin{tabular}{|c|c|c|c|c|c|c|}
\hline Case & $\begin{array}{l}\text { Age/Sex/ } \\
\text { Ethnicity }\end{array}$ & $\begin{array}{l}\text { Tumor } \\
\text { type }\end{array}$ & $\begin{array}{l}\text { Initial } \\
\text { presentation }\end{array}$ & $\begin{array}{l}\text { Interval } \\
\text { between } \\
\text { primary tumor } \\
\text { and metastasis }\end{array}$ & Treatment & $\begin{array}{l}\text { Survival } \\
\text { time after } \\
\text { metastasis }\end{array}$ \\
\hline $\begin{array}{l}\text { Pollack et al. } \\
1987[4]\end{array}$ & 62/male/NA & SCC & Asymptomatic & NA & Nephrectomy & 2 months \\
\hline $\begin{array}{l}\text { Grise et al. } \\
1987 \text { (2cases) } \\
{ }^{*}[5]\end{array}$ & $\begin{array}{l}\text { 56/male/Fren } \\
\text { ch }\end{array}$ & SCC & Hematuria & 24 months & Nephrectomy & 6 months \\
\hline$*$ & $\begin{array}{l}\text { 62/male/Fren } \\
\text { ch }\end{array}$ & SCC & Hematuria & 5 months & Nephrectomy & 6 months \\
\hline $\begin{array}{l}\text { Kitami et al. } \\
1987 \text { [6] }\end{array}$ & $\begin{array}{l}\text { 61/male/Japa } \\
\text { nese }\end{array}$ & SCC & $\begin{array}{l}\text { Left flank pain } \\
\text { and high fever }\end{array}$ & 11 months & $\begin{array}{l}\text { Nephrectomy+ } \\
\text { chenotherapy }\end{array}$ & 2 months \\
\hline $\begin{array}{l}\text { Okamoto et } \\
\text { al. 1988 [7] }\end{array}$ & $\begin{array}{l}\text { 46/female/Jap } \\
\text { anese }\end{array}$ & SCC & $\begin{array}{l}\text { Right abdominal } \\
\text { pain }\end{array}$ & 3 months & Nephrectomy & NA \\
\hline $\begin{array}{l}\text { Nagai et al. } \\
1989[8]\end{array}$ & $\begin{array}{l}\text { 50/male/Japa } \\
\text { nese }\end{array}$ & SCC & $\begin{array}{l}\text { Right flank pain } \\
\text { and macroscopic } \\
\text { hematuria }\end{array}$ & 2 years & $\begin{array}{l}\text { Nephrectomy+ } \\
\text { radiotherapy }\end{array}$ & 4 months \\
\hline $\begin{array}{l}\text { Shimizu et al. } \\
1990 \text { [9] }\end{array}$ & $\begin{array}{l}\text { 62/male/Japa } \\
\text { nese }\end{array}$ & SCC & Asymptomatic & 5 months & $\begin{array}{l}\text { Neoadjuvant } \\
\text { CCRT followed } \\
\text { by nephrectomy }\end{array}$ & NA \\
\hline
\end{tabular}




\begin{tabular}{|c|c|c|c|c|c|c|}
\hline $\begin{array}{l}\text { Miyoshi et al. } \\
1997 \\
\left(2 \text { cases) }^{*}[10]\right.\end{array}$ & $\begin{array}{l}\text { 57/male/Japa } \\
\text { nese }\end{array}$ & SCC & $\begin{array}{l}\text { Severe right flank } \\
\text { pain }\end{array}$ & 2 months & Nephrectomy & $>3$ months \\
\hline * & $\begin{array}{l}\text { 57/male/Japa } \\
\text { nese }\end{array}$ & SCC & $\begin{array}{l}\text { Severe right flank } \\
\text { pain and gross } \\
\text { hematuria }\end{array}$ & 1 years & Nephrectomy & 2 months \\
\hline $\begin{array}{l}\text { Matsushi ta et } \\
\text { al. } 1998 \text { [11] }\end{array}$ & $\begin{array}{l}\text { 74/male/ } \\
\text { Japanese }\end{array}$ & SCC & Asymptomatic & 13 months & $\begin{array}{l}\text { Partial } \\
\text { nephrectomy }\end{array}$ & 3 months \\
\hline $\begin{array}{l}\text { Mao et al. } \\
2003^{\text {a }}[12]\end{array}$ & $\begin{array}{l}\text { 64/male/Chin } \\
\text { ese }\end{array}$ & $\overline{\mathrm{ADC}}$ & Asymptomatic & 3 years & Nephrectomy & $>9$ years \\
\hline $\begin{array}{l}\text { H Huh et al. } \\
2003 \text { [13] }\end{array}$ & $\begin{array}{l}54 / \\
\text { male/Korean }\end{array}$ & SCC & $\begin{array}{l}\text { General weakness } \\
\text { and a } 3 \mathrm{~kg} \text { weight } \\
\text { loss over a month }\end{array}$ & 18 months & Nephrectomy & NA \\
\hline $\begin{array}{l}\text { Lim et al. } \\
2004[14]\end{array}$ & $\begin{array}{l}\text { 64/male/Kore } \\
\text { an }\end{array}$ & SCC & Asymptomatic & 25 months & $\begin{array}{l}\text { Nephrectomy+ } \\
\text { chemotherapy }\end{array}$ & $>2$ months \\
\hline $\begin{array}{l}\text { Ku et al. } 2005 \\
{[15]}\end{array}$ & $\begin{array}{l}65 / \text { male/Kore } \\
\text { an }\end{array}$ & SCC & Asymptomatic & 21 months & $\begin{array}{l}\text { Nephrectomy+ } \\
\text { chemotherapy }\end{array}$ & $>6$ months \\
\hline $\begin{array}{l}\text { Lai et al. } \\
2012[16]\end{array}$ & $\begin{array}{l}\text { 46/male/Chin } \\
\text { ese }\end{array}$ & SCC & $\begin{array}{l}\text { Poor appetite and } \\
\text { abdominal pain }\end{array}$ & 24 months & Chemotherapy & 24 months \\
\hline $\begin{array}{l}\text { Sun et al. } \\
2014[17]\end{array}$ & $\begin{array}{l}\text { 64/male/Chin } \\
\text { ese }\end{array}$ & SCC & Osphyalgia & 9 months & Nephrectomy & 3 months \\
\hline $\begin{array}{l}\text { Chang et al. } \\
2016[18]\end{array}$ & $\begin{array}{l}\text { 53/male } \\
\text { Chinese }\end{array}$ & SCC & $\begin{array}{l}\text { Gross hematuria } \\
\text { and left flank pain }\end{array}$ & 31 months & Nephrectomy & 2 months \\
\hline $\begin{array}{l}\text { Nam et al. } \\
2017 \text { [19] }\end{array}$ & $\begin{array}{l}\text { 47/male/Kore } \\
\text { an }\end{array}$ & SCC & Asymptomatic & 20 months & $\begin{array}{l}\text { Nephrectomy+ } \\
\text { chemotherapy }\end{array}$ & $\begin{array}{l}>49 \\
\text { months }\end{array}$ \\
\hline $\begin{array}{l}\text { The present } \\
\text { case } 2017\end{array}$ & $\begin{array}{l}\text { 58/male } \\
\text { Taiwanese }\end{array}$ & SCC & $\begin{array}{l}\text { Gross hematuria } \\
\text { and right flank } \\
\text { pain }\end{array}$ & 22 months & $\begin{array}{l}\text { Nephrectomy+ } \\
\text { chemotherapy }\end{array}$ & $>5$ months \\
\hline
\end{tabular}

${ }^{a}$ Brain metastasis occurred two years after the primary tumor had been found. NA: Not available

Table 1: Previous reported cases of esophageal cancer with kidney metastasis.

\section{Conclusion}

Clinically, renal metastasis of esophageal cancer is rare, likely due to its asymptomatic presentation. Physicians need to be alert on the possibility of renal metastasis in patient with esophageal cancer once a renal mass is found during routine follow-up. Early detection and accurate diagnosis are needed for the therapeutic plan. Despite of this account, the treatment of renal metastasis of esophageal cancer remains controversial due to its rarity of cases. The prognosis is often poor once the metastasis has occurred. Therefore, more research work is needed to improve treatment outcomes. 


\section{Conflicts of Interest}

All contributing authors declare no conflicts of interest

\section{References}

1. Ferlay J, Soerjomataram I, Dikshit R, et al. Cancer incidence and mortality worldwide: Sources, methods and major patterns in GLOBOCAN 2012. International Journal of Cancer 136 (2015): E359-E386.

2. Ministry of Health and Welfare. http ://dep.mohw.gov.tw/DOS/lp-1777-113.html (2017).

3. Siegel RL, Miller KD, Jemal A. Cancer statistics, 2016. CA Cancer J Clin 66 (2016): 7-30.

4. Pollack HM, Banner MP, Amendola MA. Other malignant neoplasms of the renal parenchyma. Semin Roentgenol 22 (1987): 260-274.

5. Grise P, Botto H, Camey M. Esophageal cancer metastatic to kidney: report of 2 cases. J Urol 137 (1987): 274-276.

6. Kitami K, Masuda M, Chiba K, et al. Metastatic renal tumor originating from esophageal carcinoma: a case report. Hinyokika Kiyo 33 (1987): 1221-1225.

7. Eiichi $\mathrm{O}$, Toshihiro $\mathrm{O}$, Tomoyoshi $\mathrm{T}$, et al. Metastatic renal tumor originated from esophageal carcinoma: A case report. Acta. Urol. Jpn 34 (1988): 1017-1021.

8. Nagai T, Takashi M, Sakata T, et al. A case of esophageal cancer metastatic to the kidney presenting as renal pelvic cancer. Hinyokika Kiyo 35 (1989): 1565-1568.

9. Shimizu H, Koyama Y, Ozawa I, et al. An esophageal cancer with a renal metastasis that was detected and resected as the only focus of recurrence. Gan No Rinsho 36 (1990): 2047-2052.

10. Miyoshi Y, Asakura T, Matsuzaki J, et al. Metastatic renal tumor originating from esophageal cancer: report of 2 cases. Hinyokika Kiyo 43 (1997): 347-350.

11. Matsushita Y, Katoh T, Isurugi K, et al. Metastatic renal tumor originating from esophageal carcinoma: a case report. Hinyokika Kiyo 44 (1998): 591-594.

12. Mao YS, Suntharalingam M, Krasna MJ. Management of late distant metastases after trimodality therapy for esophageal cancer. Ann Thorac Surg 76 (2003): 1742-1743.

13. Huh H, Kim W. Esophageal Cancer Metastasis to the Kidney. Annals of Surgical Treatment and Research 64 (2003): 80-83.

14. Lim DH, Im YH, Ji SH, et al. Esophageal squamous cell carcinoma recurring as a solitary renal mass. Cancer Res Treat 36 (2004): 271-274.

15. Ku JH, Park HK, Lee E, et al. Solitary squamous cell carcinoma in the kidney after metachronous development of esophageal and lung cancer. Tumori 91 (2005): 93-95.

16. Lai YC, Lai JI, Lin PC, et al. Esophageal Squamous Cell Carcinoma with Solitary Renal Metastasis-A Case Report. J Gastroenterol Hepatol Res 1 (2012): 230-232.

17. Sun Y, Yu X, Zhang Y. Renal metastasis after esophagectomy of esophageal squamous cell carcinoma: a case report and literature review. World J Surg Oncol 12 (2014): 165.

18. Chang KP, Huang CP, Chang H. Solitary renal metastasis of esophageal squamous cell carcinoma mimicking primary renal neoplasm - A case report and literature review. BioMedicine 6 (2016): 35-39. 
19. Nam KS, Jung K, Park MI et al. Esophageal Cancer with Solitary Renal Metastasis Treated with Multidisciplinary Therapy: A Case Report and Mini Review of the Literature. The Korean Journal of Helicobacter and Upper Gastrointestinal Research 17 (2017): 39-44.

20. Napier KJ, Scheerer M, Misra S. Esophageal cancer: A Review of epidemiology, pathogenesis, staging workup and treatment modalities. World J Gastrointest Oncol 6 (2014): 112-120.

21. Siewert JR, Ott K. Are Squamous and Adenocarcinomas of the Esophagus the Same Disease?. Seminars in Radiation Oncology 17 (2007): 38-44.

22. Rice TW, Khuntia D, Rybicki LA, et al. Brain metastases from esophageal cancer: a phenomenon of adjuvant therapy Ann Thorac Surg 82 (2006): 2042-2049.

23. Anderson LL, Lad TE. Autopsy findings in squamous-cell carcinoma of the esophagus. Cancer 50 (1982): 1587-1590.

24. Choyke PL, White EM, Zeman RK, et al. Renal metastases: clinicopathologic and radiologic correlation. Radiology 162 (1987): 359-363.

25. National Comprehensive Cancer Networks (NCCN). NCCN practice guidelines for cancerrelated fatigue (2017).

26. Israel GM, Bosniak MA. How I Do It: Evaluating Renal Masses 1. Radiology 236 (2005): 441-450.

27. Urban BA, Buckley J, Soyer P, et al. CT appearance of transitional cell carcinoma of the renal pelvis: Part 2. Advanced-stage disease. AJR Am J Roentgenol 169 (1997): 163-168.

This article is an open access article distributed under the terms and conditions of the Creative Commons Attribution (CC-BY) license 4.0 